\title{
sciendo
}

\section{Interdependence between international migration and evolution of development gaps}

\author{
Angelica BĂCESCU-CĂRBUNARU \\ The Academy of Economic Studies, Bucharest, Romania \\ mihaela.carbunaru@csie.ase.ro
}

\begin{abstract}
Migration plays an important role in almost all objectives of sustainable development. In the '80s and '90s, many authors debated the non-deterministic character of the impact of migration on the development of primarily the countries of origin. Migration as a complex process in globalization has amplified relations between states but there have been very rare reductions in development gaps between them that in turn discourage labour migration. In spite of the increase in well-being based on theory, practice has always revealed an asymmetric development that causes an increase in the differences between emigration and immigration countries.

The global strategy for poverty eradication adopted by world leaders in 2000 did not include migrationrelated targets, probably because the link between migration and development had not yet been properly perceived. Since then, studies, policy analyzes, international forums and migration recommendations have focused on policy-making in practice, including efforts to support migration concerns in the post-2015 development agenda. Various ideas and recommendations were presented during that data on the most appropriate way to use the migration-development link to maximize its positive effects. In 2015 was adopted the 17 Sustainable Development Goals (SDGs) of the 2030 Agenda for Sustainable Development. Starting with these documents, the contribution of migration to sustainable development was officially recognized for the first time.

From the beginning remittances have played an important role in setting migration as the most important development factor. We sustained that this view, on which allmost all national policies are based, distorts the notion of development and hide the main causes of current labor migration. In this context, this study also attempts to analyze the two-way relation between the factors that determine human development (income, education and health) and international migration.

Managing migration is one of the most important issues of global cooperation.
\end{abstract}

Keywords: migration and development nexus; economic and human development; Human Development Index (HDI); remittances; diaspora; development gaps

\section{Introduction}

Migration plays an important role in all the objectives of sustainable development. The migration-development nexus is a topic of growing interest among international organizations primarily on how regional migration policies support global development as well as to control as far as possible the effects of underdevelopment on migratory flows.

From different reasons, those organizations see remittances as an essential tool in the development of migrant-sending, for the most part underdeveloped countries. Wise and Marquez (2009) sustained that this limited and deformed perspective should be minimized and the migration-development relationship should be considered in a comprehensive manner, including structural global approaches based on the political economy of 
development. This type of analysis should take into account the forces cultural, ecological, economic, political and religious that drives mobility and temper outcomes (Birgitte Mossin Brønden, 2012).

Diaspora has begun to promote the development of the host country and, at the same time, the country of origin. International organizations have understood the importance of these issues and have endeavored to implement the results obtained with different programs in national and regional policies. We can recall here the permanent steps of the Migration Policy Institute. As their representatives (Papademetriou, D., G., Newland, K., 2014) have proposed, MPI's Migrants, Migration, and Development Program discusses the interdependence between the policies and trends that characterize migration at present and the phenomenon of development, going beyond the basic concept that development can counteract migration or that migration is a treatment for development.. The program's focus is on nuanced policy guidance for countries of destination and origin regarding the actual and potential contributions of migrant communities to sustainable development for both, origin and host countries, and the reduction of poverty in their native homelands.

According the ideas of the new economics of labour migration and livelihood approaches, the empirical analyzes sustained that, often, migration is not the ultimate solution to get rid of misery and unemployment. "Most evidence supports the view that migration rather is a deliberate attempt by social groups (typically, but not exclusively, households) to spread income risks, to improve their social and economic status and, hence, to overcome local development constraints" (De Hass 2010). The NELM researchers "tend to see migration as an expression of strong social bonds and of the wish to improve the lives of those left behind". The analysis also exemplified that migration is a phenomenon that is part of the transformation processes within the development concept, but also has its own dynamics, clearly influencing the development process. "Studies on migration and development should also leave room for qualitative, non-survey based, research techniques, which unveil patterns and structures that surveys are usually not able to capture. In general, there is an enormous potential for combining quantitative and qualitative research techniques to improve our understanding of the complex and multifaceted migrationdevelopment relationship" (De Hass 2010).

The analysis of global migration trends shows that migration generally flows from countries with lower indicators of human development to those with higher ones. According to 2009 statistics data, over $75 \%$ of the international migrants migrate to countries with a higher level of human development (Human Development on the Move, Human Development Report, 2009, p. 2.). This indicates that the human development situation and trends decisively affect a country's migration indicators and trends. It is important in this respect to analyze the substance of the Human Development Concept, a prevalent development framework that is globally used to measure the development progress and achievements of states. Interestingly, the countries that have adopted development policies based on a HD framework, i.e. have economic, political, cultural and social systems that focus on creating and promoting an atmosphere in which human potential can grow and freedom of choice can be safeguarded, have the most diversified and advanced economies that, through their demand for human labour, promote the continuous improvement of education systems and the creative capabilities of humans not only in the respective countries, but also throughout the world. The labour markets of those countries are typically open to those citizens of the world that are better qualified and have human-centred views of the world. In the case of 
highly-qualified individuals, migration is often due to not only the pursuit of higher remuneration, but also the convenience of an environment for one's views of the world, which supplies greater opportunities and stimuli for creative individuals to continuously develop and realize their potential regardless of the spheres of their professional occupation.

Development should not be viewed as a purely economic matter as it also involves human rights. Respect for human rights reinforces the migration-development nexus. Hence, the migration policy should be part and parcel of a comprehensive development strategy, ensuring the consistency of policy and the interconnection between migration and development. Migration, thus, can contribute positively to the realization of the right to development (Gevorgyan, V., et all, 2009). The international migration processes, in recent years have been multifaceted phenomena directly connected with human development issues. Due to various aspects of the traditional family and social culture, migration has become a unique means of improving the conditions for human development. To analyze these issues substantively, one needs first to understand the new global trends concerning human development, the extent to which the human development challenges are connected with the migration process and the current and anticipated positive and negative effects of migration on human development. "The goal of human development should lie at the heart of the migration policy" (Gevorgyan, V., et all, 2009).

\section{Literature review}

The link between migration and development evolved, as Hein de Haas said, as a pendulum in the post-war period, from the optimism of modernist development to brain drain pessimism, to the neo-optimistic euphoria of brain earning and remittances, factors that characterize it relationship since the beginning of the new millennium (de Haas 2012). The issue is not new to the international community but, whether positive or negative, migratory pressures are causing social cohesion and, combined with humanitarian and development aid budgets, these tensions may partially explain the increased interest after 2000 in an attempt to formulate migration development policies (Vammen and Mossin Brønden 2012). Alternatively, some researchers might call these two radically opposed approaches: the "balanced growth" versus "asymmetric development" theories (De Haas 2010).

Under the influence of post-modernist thinking and implicitly of Giddens's (1984) structuring theory, social science researchers have tried to adapt approaches focused on agency and structure. The heterogeneity of migration-development nexus it is easier to understand in these circumstances. Scheldon (2008) sustained that "in such a pluralist approach, the results of the structure-actor interactions allow for a greater variety of outcome than would have been allowed from either the single aggregation of individual decision making or from the unidirectional imperatives of structures". Thus, the paradigm shift in social theory has influenced, among others, the scholastic approach of the migrationdevelopment relationship. The most important ideas were stated in the last two decades of the twentieth century by NELM representatives. In 2010, from the desire to justify the heterogeneous character of the interdependence between migration and development, de Haas analyzes the three directions of approach and shows how they can be harmonized to provide a clearer perspective of the interdependence between the phenomenon of migration and development processes.

A very argued research of Mrs. Kathleen Newland, Co-Founder of the Migration Policy Institute, explains the following fundamental issues of the relationship between migration 
and development. "The benefits of remittance income to source countries do not necessarily explain the full impact of remittances on poverty. Remittances may not constitute a rising tide that raises all boats, but they do have a very important effect on the standard of living of the households that receive them, constituting a significant portion of household income. They are an important social safety net for poor families, possibly reducing additional outmigration in particularly difficult times. Many students of migration agree that the transnational networks are today the most important developmental resource associated with international migration. A realistic response requires abandoning the 'brain drain' approach of trying to keep the highly skilled at home. More likely to succeed is a Diaspora model, which integrates past and present citizens into a web of rights and obligations in the extended community defined with the home country as the center" (Newland, K., 2003).

\section{Research methodology, data, results and discussions \\ The impact of migration on development and the rebound of this phenomenon}

The main aim of development is to provide people a suitable environment for them to enjoy a long, healthy o education, a long and healthy life and a satisfactory life standard (UNDP, 1990: 9-10). "The increasing migration waves in the world indicate that people use their freedom of migration so as to improve their human development levels" (Orhan Kandemir, 2012).

The study aims to explain whether human development and factors (income, education, and health) that are used to measure human development are influenced by the migration process and vice-versa. Within this framework, the following questions were tried to be answered: Income remains the most important factor influencing the phenomenon of migration, as did the begining of the 21th century (remmitances boom was main consequences)? Do migrants really find an opportunity to increase their human development, and thus their welfare? The fact that income became a secondary factor for a large number of emigrants supports their destination. Thus, only one third of total international migration is from underdeveloped to developed countries (south-north migration). One third is the one called north-north and one third called south-south. A lot of other factors determine the migrant decision regarding destination country. „For instance, increased wealth in combination with improved education, increased media exposure, and the (concomitant) confrontation with the higher wealth of other people may increase feelings of relative deprivation, and may give rise to higher aspiration levels and, therefore, increased migration, as long as increases in aspirations outpace increases in local opportunities. Moreover, slight increases in absolute wealth may enable many more people to bear the opportunity costs and risks of migrating. Therefore, decreased wage and other opportunity differentials often lead to increased migration" (De Hass 2008). The intensity of the migration is influenced by the aspirations of the people, a factor that is usually omitted by the neoclassical, structuralist and push-pull models in which the needs are somehow supposed to be constant and decisive - but it is essential in understanding the migration phenomenon (De Hass 2008). People's lusts are not constant and most often their level determines the image of an overpopulation perceived in relation to the opportunities of the local economy. ( De Haas cf. Petersen 1958:259). 


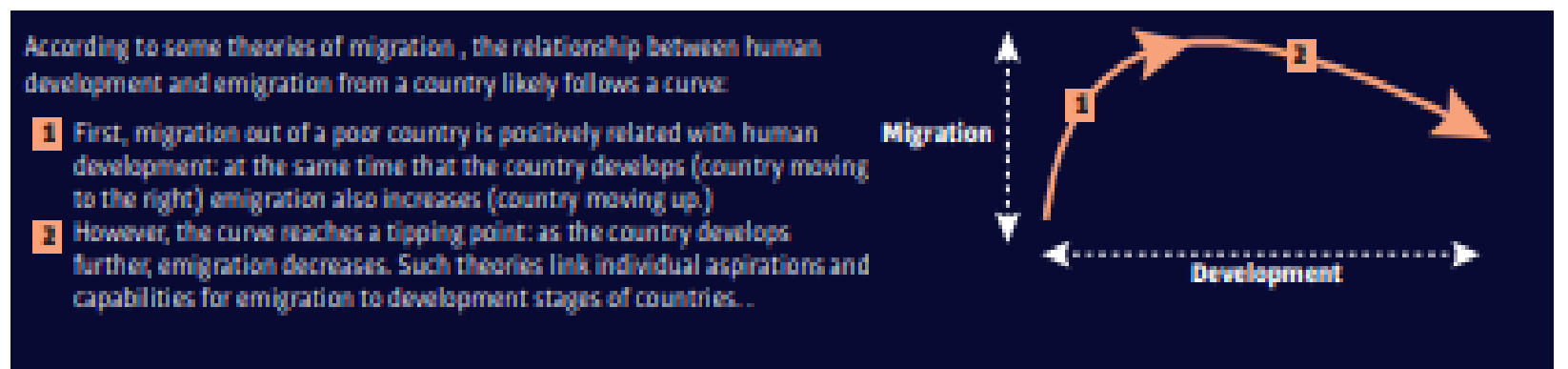

Fig. 1 Interdependence between migration and development

Source: European Comission

The fundamental idea is that socio-economic development tends to increase people's capabilities and aspirations to migrate (De Hass 2010). The question is why some countries manage to go through the development process without having to send millions of citizens abroad. "Development should indeed be about creating the conditions for people to decide if they prefer to stay home or leave. But thinking that emigration is a condition for development would be a big mistake. Policy makers can only try to make the best of it through adequate and coherent policies" (Khoudour, D., OECD, 2015). When we speak of development, we should mean social progress as well as economic growth. Both conditions make the difference between the level of development of developed and underdeveloped countries.

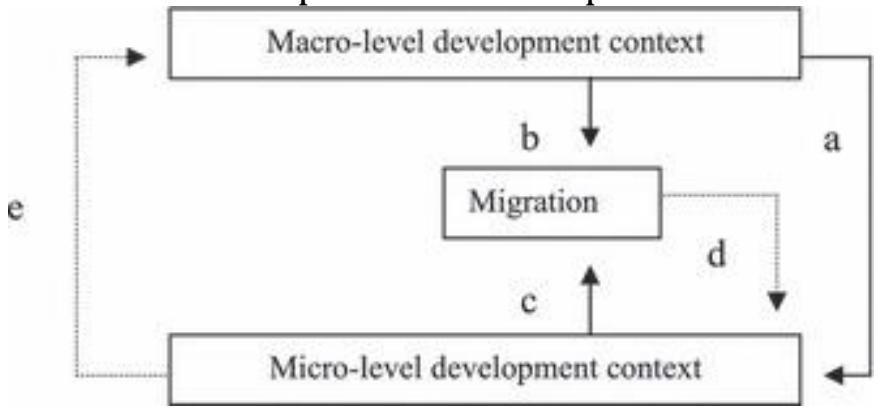

Fig. 2. General Conceptual Framework for Analyzing Migration-development Interactions Source: De Haas, 2010

The results of the empirical and theoretical analyzes approached at the end of the 20th century and the beginning of the 21st century support the heterogeneous character of the relation between the phenomenon of migration and the development processes on the one hand and their spatio-temporal relationship. De Haas sustained that "migration is not an independent variable causing development (or the reverse), but is an endogenous variable, an integral part of change itself and a factor that may enable further change". For this reason, it is more fair to refer to the univocal relationship between the phenomenon of migration and development at the macro level, instead of the unidirectional influence of migration on development processes. Figure 2 schematizes this reciprocity of the interdependencies between the migration phenomenon and the development processes. „When analysing the factors which underlie the differentiation in migration and development relationships, a distinction can made between (I) the development context at the general, macro (national, international) level; (II) the development context at the local or regional level; and (III) the factors related to the migrant and her direct social and economic environment on the household, family and community level. These three sets of variables are mutually linked 
through various direct functional relations and feedback mechanisms" (De Haas, 2010).

But migration rates will rise because, „as low-income countries move to middleincome status, the pressure for their working-age populations to emigrate will grow because economic development generates new opportunities and motivations for migration" (Clemens 2014). According to MPI analysts was proposed some policies to raise the development impact of migration: seek to expand the legal rights of citizens overseas; improve migrants' access to financial services; take advantage of the unusual opportunity to focus self-discovery and enterprise promotion efforts on small-scale activities; encourage citizens overseas to retire at home. "The world needs better ways to manage international migration for this century. These better ways finally have a roadmap (Michael A. Clemens \& Kate Gough 2018): The Global Compact for Migration. Now the journey begins". National governments must intelligently drive processes that accompany the migration phenomenon to implement this pact and need instruments. A promising tool is to set up Global Skill Partnerships (GSP). In addition to the more traditional law enforcement tools on migration and development assistance, the world urgently needs new policy tools to better manage migration for all involved. GSP offers one of the innumerable innovations needed.

In our country, unfortunately, besides the high volume of remittances over the last 15 years with immediate consequences (consumption increase) or medium and long term (acquisition of movable and immovable property) in the welfare of the family and possibly aspects of social gain and civility acquired by returning emigrants (Sirca, 2014), we can not talk about notable results regarding the positive effects of migration on development. Investing in children's education up to university studies abroad can not be considered as a positive solution because most of the time young people do not return to the country because of socio-economic shortcomings and the lack of predictability often associated with encouraging and supporting definitive emigration from the family.

As an important positive development factor, besides remittances, the role that Romanian emigrants can play as "ambassadors" in attracting direct investment from the countries of adoption (Roman, Strat, 2018) should be taken into account. But as long as predictability, legislative instability, corruption and substantial infrastructure gaps are major obstacles to FDI activity in an economy such as the Romanian one, it is hard to observe the positive macroeconomic effects of this phenomenon. In light of Romania's labour emigration and rising wage pressures, the country will become less attractive to foreign investors, causing the economy to grow at a slower pace (L. Gordon\& M. Eghbal, 2007).

\section{Human Development Index (HDI) - features for international migrants}

To determine the impact of migrant status on HDI, Ravinder Mamtani, Albert B. Lowenfels, Sohaila Cheema and Javaid Sheikh published, in 2014, a short report called "Impact of migrant workers on the Human Development Index" in the journal Perspectives in Public Health.

The study shows that for countries with a large number of immigrants, the schooling period can be shortened because, to a large extent, immigrants are unskilled workers, with a low level of education compared to the native population. On the other hand, the expected component of the years of studies would not be affected by the number of immigrants, because it is determined by the number of students enrolled in the education system. The main aspect pursued in the study is to analyze how the status of immigrants influences the HDI class score. The researchers analized 93 countries classified as high or very high human 
development because this group has the highest concentration of migrant guest workers (see table 1). The main steps were to plotted the country-specific ranking of each of the three individual HDI components (education, health, income) against migrant status. After that they plotted each of the three components against the overall HDI, using a marker to identify those countries with the highest proportion of migrant workers. The researchers used linear least squares analyses to study the relationship between migrant status and HDI as well as the individual components of the HDI.
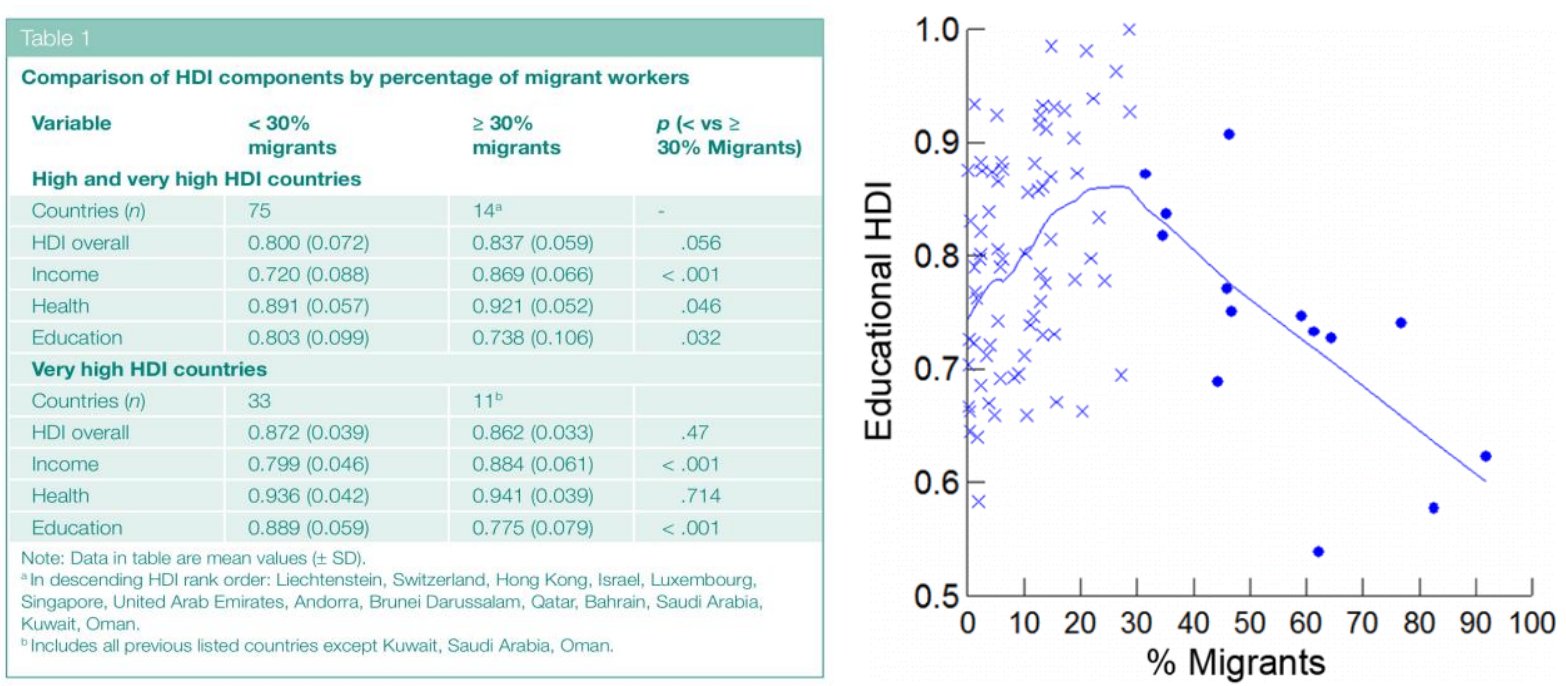

Fig. 3 Corelation between migrants' number and educational component of HDI

Source: Perspectives in Public Health; 2014

When they plotted the educational component of the HD against the percentage of migrants in these countries, was noticed a biphasic curve with an inflexion point when the percentage of migrant workers in the population reached 30\%. "After this level was reached, there was a robust negative correlation between the educational component of the HDI and percentage of migrant workers" (Mamtani, R., et all, 2014). The migrant worker status affects mainly the educational component of the HDI. Income earned by migrant workers is generally sent home and is not taxed in the host country. With respect to the health HDI, only healthy workers are granted work permits. The conclusion of the study was that migrant guest worker status distorts the overall HDI ranking because it has a measurable negative impact on the educational component. For the countries in the two highest HDI categories, there are 14 countries with more than 30\% of migrant guest workers whose ranking is significantly impacted by the high proportion of migrant guest workers. The current HDI ranking of any country with a high proportion of migrant workers in the population should be interpreted cautiously. below.

The relationship between HDI and migration is shown in European Commission chart, 


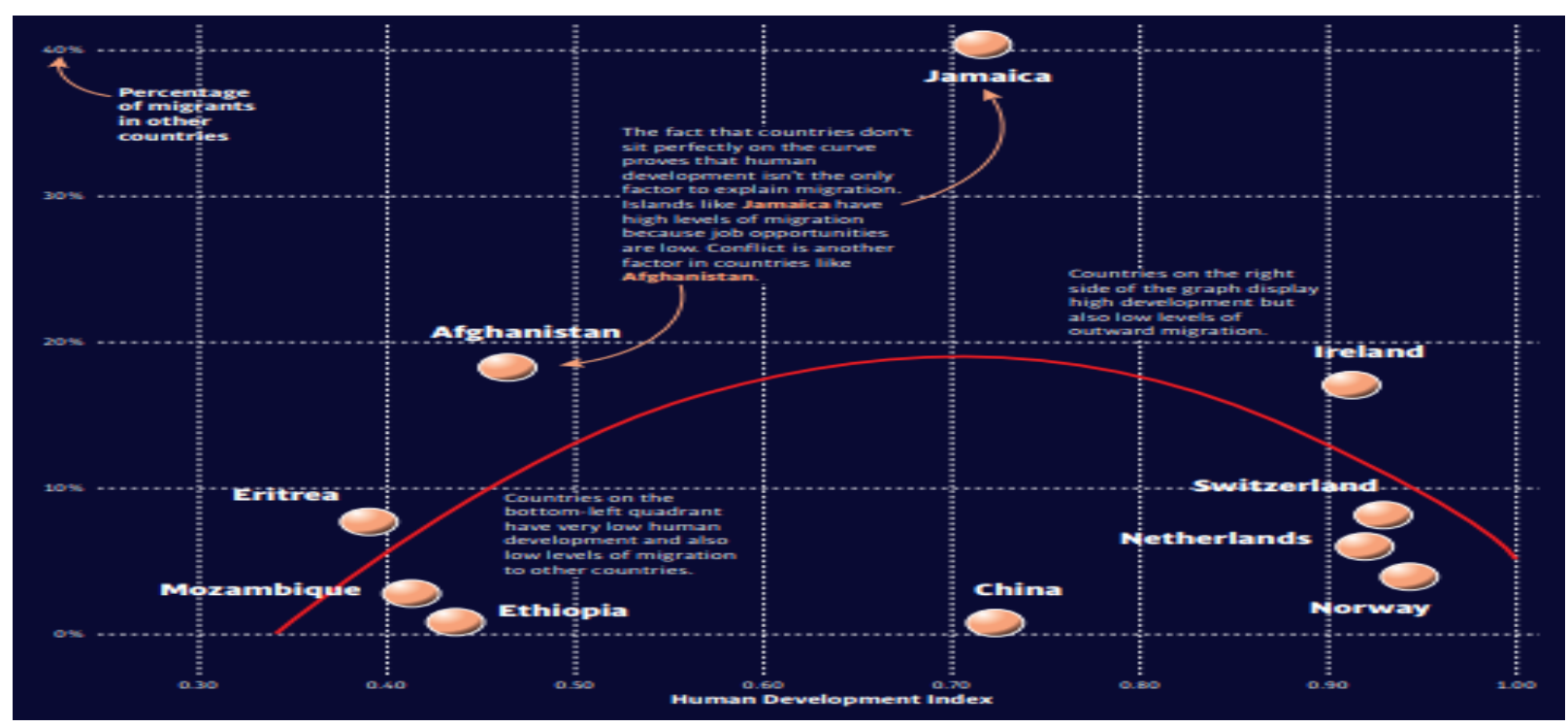

Fig. 4 The relationship between HDI and migration

Source: European Comission,2015

\section{Diasporas - new partners in global development policy}

In most states characterized by significant migration flows, Diasporas play an increasingly important role in shaping policies on external assistance and development processes. The governments of the source countries strive to attract both the material resources and the professional knowledge of the emigrants and their descendants. The governments of the host countries that have set out to send aid, hope to improve the implementation of development assistance, by using the knowledge and skills of Diasporas. "Independently of governments, many diaspora groups or individuals recognize profitable opportunities in their homelands, or contribute their time, talents, and resources to improving the quality of life there" (K. Newland, MPI, 2010). The MPI studies examine the development impact of diaspora in six fields: entrepreneurship, capital markets, "nostalgia" trade and "heritage" tourism, philanthropy, volunteerism, and advocacy.

Migrants and their descendants play an important role in stimulating the development of their countries of origin, by investing in businesses, participating in heritage tourism, and engaging politically or philanthropically. Diaspora expertise can enhance aid efficiency and facilitate skills and knowledge transfer. The presence of a diaspora stimulates trade between countries of origin and host countries, by creating connections between producers and consumers and simply buying home country products and introducing them to others. The existence of a migrant network also increases direct investments: both due to the diaspora's own investments, especially valuable in countries considered as risky by foreign investors, and by reducing transition and information costs for other investors. "A diaspora's positive contribution depends to a large extent on homeland governments creating an enabling environment for emigrants' involvement and the degree of their integration in the host country" (Latek, M., EPRS, 2019).

\section{The role of remittances in recent years and the "brain drain" phenomenon}

Remittances sent back to developing countries rose from $\$ 31.1$ billion in 1990 to $\$ 76.8$ billion in 2000 to $\$ 167.0$ billion in 2005. "There is a growing belief that remittances are a more 
effective instrument for income redistribution, poverty reduction and economic growth than large, bureaucratic development programmes or development aid" (Kapur 2003). Statistical data show that in 2017, migrants from developing countries sent home an estimated $\$ 450$ billion, three times the volume of official development assistance (ODA). At the same time, remittances represent a considerable percentage of GDP: for example, around 30\% for Tajikistan, Kyrgyzstan and Haiti, about 10\% for Egypt, the Philippines or Guatemala. The impact of these important amounts on the growth of the investments in production was not demonstrated because the impact on the economic growth was mostly insignificant. However, it is clear that they are a very effective intervention in terms of poverty reduction in households. Remittances are spent largely for daily consumption and access to health services and sometimes for education. The analyzes of recent years have highlighted the gains for households in the source countries, in terms of reducing the degree of indebtedness, thus implicitly of poverty, increasing consumption and even developing family assets represented by households and land related to households. "However not all migrants are willing and able to send remittances, so for some households the negative impact in terms of lost labour of one of its members will not be compensated by the positive effects of money transfers" (Latek, M., EPRS, 2019). "Far from being productive, remittances may increase inequality, encourage consumption of imports, and create dependency. They are often delivered with stunning inefficiency; as much as 20 percent of their value is said to disappear, commonly through high transfer fees and poor exchange rate offerings" (K. Newland, MPI, 2003).

"After decades of pessimism and concerns on brain drain, governments of migrant sending countries have put renewed hopes on transnationally oriented migrants and 'Diasporas' as potential investors and actors of development" (De Haas \& Plug 2006; Gamlen 2006; De Haas 2008). Transforming brain drain into brain growth through circular or temporary migration schemes is generally presented as an important variant and for years to come. Romania faces an emigration of highly qualified personnel and a political and economic climate that affects its economic development and the quality of life of the population. Under these conditions, the issue of the shortage of highly qualified personnel, especially from the areas with social (medical) or economic impact (innovation, research development), needs to be approached responsibly and strategically by the decision makers. "Promoting skilled regular migration and integration of immigrant workers, including helping them to make full use of their education while working abroad, would avoid deskilling, failure of migration projects and provide a potentially positive impact in terms of poverty reduction" (Latek, M., 2019).

\section{Conclusions}

Analyzing the determinants of migration and its impact on development processes, we observe that a certain compromise will be needed from both development policy and migration policy actors, to balance the interests, approaches and perspectives that create divergence between the two phenomena. As to development policy, although narrow economic definitions of development, especially GDP growth per capita, are still used in empirical studies, the picture is today completed with wider concepts of human development, and more recently, sustainable development. The diaspora in the host countries play a particularly important long-term role in shaping migration flows. The 
connections between the members of a diaspora and the family and friends in the country of origin are a determining factor in the migration phenomenon. "To impact deep-seated drivers of migration, a careful contextual analysis of each national and regional configuration is needed to establish long-term adjustable programmes" (Latek, M., EPRS, 2019).

Romania's chance lies in the implementation of regional and local policies to boost the positive effects of migration on development. But this requires politicians to put national interest before personal and group interests as happened after 1989. As long as due to conditions in the medical system, migration of health has been and still is major, we can not get even of the possible FDIs that would arise, nor of the funds made available by the EU to develop this sector as we almost lacked qualified staff. Those who are left in the country are not able to specialize by conveying them to congresses and conferences because small salaries do not allow them to improve. The example of Mindea neurosurgeon is eloquent for how bad it has done and continues to do bureaucracy in this vital area of society, but its success allows us to hope for the results of a possible return migration. Emigration continued with successive waves in a large number of categories of citizens that could contribute to Romania's development and, no matter how we look at statistics, this is a significant loss in all spheres of life, with long-term socio-economic consequences that is hard to anticipate. Obviously, Romanians decide to leave their home country not only because of the net salary level. There are other socio-economic factors that determine the emigration decision, but satisfaction with salary income is important.

A certainty is that as long as there will be significant development gaps between countries, there will be massive migration flows. The main conclusion is that migration affects development, but development also affects migration. These are not simple relationships. "Regional development does not always drive to less migration, the brain drain may not be bad for the human capital levels of the migrant-sending countries and remittances may not always be beneficial to the receiving economies" (Vargas-Silva, C., 2012).

After several decades of growth in emerging economies, a period in which few countries have advanced from low to middle or high income status, the gaps in wealth and general welfare still remain high. Despite years of growth, especially job creation it has not kept pace with the rise in the working age population in most developing countries, and salaries remain considerably lower than in developed economies. As we have seen in several analyzes and studies on international migration, rapid economic growth in low-income countries in fact leads to increased migration, as more people now have the economic means to migrate, and the gaps between rich and poor countries remain fairly large. With appropriate policies, global demographic changes caused by international mobility can become an opportunity for economic and human development, influencing at macroeconomic level the narrowing of the gap between developed and underdeveloped countries.

\section{References}

Clemens, M., A., (2014). Does Development Reduce Migration?; Center for Global Development, NYU Financial Access Initiative and IZA; Available at: http://ftp.iza.org/dp8592.pdf

Clemens, M., A., Gough, K., (2018); A Tool to Implement the Global Compact for Migration: Ten Key Steps for Building Global Skill Partnerships; Available at: https://www.cgdev.org/publication/tool-implement-global-compact-migration-tenkey-steps-building-global-skill-partnerships.pdf 
De Haas, H., (2010). Migration and development: a theoretical perspective. International Migration Review 44: 227-264; Available at:

https://www.researchgate.net/publication/227539598_Migration_and_Developmen t_A_Theoretical_Perspective1

De Hass, H., (2012). The Migration and Development Pendulum: A Critical View on Research and Policy; Available at: https://heindehaas.files.wordpress.com/2015/05/de-haas28201229-the-migration-and-development-pendulum-a-critical-view-on-researchand-policy.pdf

Delgado Wise R, Márquez Covarrubias, H. (2009). Understanding the relationship between migration and development: toward a new theoretical approach. Social Analysis 53: 85-105; Available at:

https://www.researchgate.net/publication/233585857_Understanding_the_Relatio nship_Between_Migration_and_Development_Toward_a_New_Theoretical_Approach

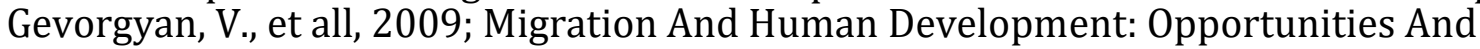
Challenges; National Human Development Report 2009; Available at: http://hdr.undp.org/sites/default/files/nhdr-2009-armenia-en.pdf

Gordon, L., Eghbal, M., (2007); Romanian migration raises concerns over labour shortage; Euromonitor from UNCTAD and Eurostat; Available at: https://blog.euromonitor.com/romanian-migration-raises-concerns-over-labourshortage

Human Development on the Move, Human Development Report, (2009). Available at: http://hdr.undp.org/sites/default/files/reports/269/hdr_2009_en_complete.pdf

IOM. (2013). World migration report 2013: Migrant well-being and development. Geneva: International Organization for Migration; Available at: https://publications.iom.int/system/files/pdf/wmr2013_en.pdf

Kandemir, 0., (2012). Human Development and International Migration; Procedia - Social and Behavioural Sciences; Volume 62; pg. 446-451; Available at: https://core.ac.uk/download/pdf/82719009.pdf

Kapur, D. (2003) Remittances: The New Development Mantra? United Nations Conference on Trade and Development, Geneva; Available at: https://www.g24.org/wpcontent/uploads/2016/01/REMITTANCES-THE-NEW-DEVELOPMENT-MANTRA.pdf

Khoudour, D., (2015). Is migration good for development? Wrong question!; OECD Development Centre; Available at: http://www.oecd.org/development/developmentposts-migration-development.htm

Latek, M., (2019). Interlinks between migration and development; European Parliamentary Research Service; Available at:

http://www.europarl.europa.eu/RegData/etudes/BRIE/2019/630351/EPRS_BRI(2 019)630351_EN.pdf

Mamtani, R., et all, (2014), Impact of migrant workers on the Human Development Index; Journal Perspectives in Public Health; Available at: https://www.researchgate.net/publication/237060426_Impact_of_migrant_workers _on_the_Human_Development_Index

Mossin Brønden; B., (2012). Migration and Development: The Flavour of the 2000s; International Migration Vol. 50(3); Available at: https://vdocuments.site/migrationand-development-the-flavour-of-the-2000s.html

Newland, K., (2003). Migration as a Factor in Development and Poverty Reduction; Available at: https://www.migrationpolicy.org/article/migration-factordevelopment-and-poverty-reduction

Newland, K., (2010).Diasporas - New Partners in Global Development Policy; MPI Washington DC; Available at: https://www.migrationpolicy.org/research/diasporasnew-partners-global-development-policy

Newland, K., Plaza, S., (2013). What we Know About Diasporas and Economic Development, Policy Brief No. 5, Migration Policy Institute, London; Available at: https://www.migrationpolicy.org/research/what-we-know-about-diasporas-and- 
economic-development

Papademetriou, D., G., Newland, K., (2014). How Migration Can Advance Development Goals; Available at: https://www.migrationpolicy.org/research/how-migration-canadvance-development-goals

Roman, M., Strat, V.A. (2018), "Romanian immigrants and the inflows of foreign direct investment towards Romania", Management \& Marketing. Challenges for the Knowledge Society, Vol., 13, No 4, pp. 1226-1241. DOI: 10.2478/mmcks-2018-0033; Available at: https://www.researchgate.net/publication/330680308_Romanian_immigrants_and the_inflows_of_foreign_direct_investment_towards_Romania

Sirca, V., (2014). Migraţia Românească Postdecembristă: Focus grup cu specialiști; Analele Inst. de Ist. „G. Bariţiu” din Cluj-Napoca, Series Humanistica, tom. XII, 2014, p. 65-95; Available at: http://www.humanistica.ro/anuare/2014/Continut/02_04_Sirca_2014.pdf

Skeldon, R., (2008). Migration and Development; Available at: https://www.un.org/en/development/desa/population/events/pdf/expert/14/P04 Skeldon.pdf

UNDP, 1990: 9-10; Human Development Report 1990; Available at: http://hdr.undp.org/sites/default/files/reports/219/hdr_1990_en_complete_nostat s.pdf

Vammen, I., M.; Mossin Brønden, B., (2012). Donor-Country Responses to the MigrationDevelopment Buzz: From Ambiguous Concepts to Ambitious Policies?; Available at: https://publications.iom.int/books/international-migration-vol-503-2012migration-and-development-buzz-rethinking-migration

Vargas-Silva, C., (2012). Migration and Development; The Migration Observatory at the University of Oxford; Available at:

https://migrationobservatory.ox.ac.uk/resources/primers/migration-anddevelopment/

https://publications.iom.int/system/files/pdf/global_migration_indicators_2018.pdf http://hdr.undp.org/sites/default/files/2018_human_development_statistical_update.pdf https://migrationdataportal.org/themes/sustainable-development-goals-sdgs-0 http://pubdocs.worldbank.org/en/468881473870347506/Migration-and-DevelopmentReport-Sept2016.pdf 